\title{
A STUDY ON METOPIC SUTURE IN CADAVERIC SKULLS OF ASSAMESE PEOPLE
}

Rubi Saikia ${ }^{1}$

\section{HOW TO CITE THIS ARTICLE:}

Rubi Saikia. "A Study on Metopic Suture in Cadaveric Skulls of Assamese People". Journal of Evolution of Medical and Dental Sciences 2014; Vol. 3, Issue 44, September 15; Page: 10910-10914,

DOI: $10.14260 /$ jemds/2014/3424

ABSTRACT: Metopic suture is formed due to failure of union of the two halves of the frontal bone. Usually the suture disappears by early childhood, but in some cases it persists as complete or incomplete metopic suture throughout life. A complete metopic suture extends from anterior aspect of bregma to the nasion which is known as metopism. The present study is carried out in 126 dry human cadaveric skulls collected from the Dept. of Anatomy, Dept. of Forensic Medicine and Institute of Pharmacy at Assam Medical College \& Hospital, Dibrugarh, Assam, and India. Metopic suture was found in 46(36.5\%) skulls. Metopism was found in 4(3.17\%) skulls and incomplete metopic suture was seen in 42(33.33\%) skulls. 80(63.49\%) skulls did not have metopic suture in any form.

KEYWORDS: Metopic Suture, Metopism, Nasion, Bregma.

INTRODUCTION: The metopic suture is a vertical suture running between the two halves of frontal bone from the anterior aspect of anterior fontanelle to nasion. It is formed due to failure of fusion between the two halves of frontal bones. At birth the two halves of frontal bone remain separated by the metopic suture and the suture closes before puberty. According to Keith,(1) the metopic suture disappears at the end of first year or beginning of second year of life.

According to Romanes, (2) the metopic suture normally closes by fifth or sixth year. Warwick \& Williams (3) states that the two halves of the frontal bone begin to unite in second year and the suture is generally obliterated by the eighth year. Hamilton ${ }^{(4)}$ claims that the metopic suture disappears by seventh year of life. Fusion of this suture commences at the anterior fontanelle i.e., bregma and terminates at nasion. Sometimes when it fails to ossify and persists as a complete suture extending from bregma to nasion, it is called metopism.

The incidences of metopism vary among population of different regions and different races as reported by various workers. In the present study a humble attempt has been made to know the incidence of metopic suture in Assamese population of Assam, India. This study was carried out on 126 dry human skulls collected from the Dept. of Anatomy, Dept. of Forensic science \& Institute of Pharmacy at Assam Medical College and Hospital, Dibrugarh, Assam, India. The skulls were observed macroscopically for metopic suture and divided into three groups.

The first group included skulls without any metopic suture, second group included the skulls with complete metopic suture i.e., metopism and the third group included the skulls with incomplete metopic suture. The skulls of the third group were further sub grouped according to the shape of the suture as - Linear, U shaped, Inverted U shaped, H shaped, V shaped and Y shaped. Data found on examination was recorded, tabulated, photographed and compared with the findings of other studies.

RESULTS: Among the 126 human skulls included in this study, 80 (63.49\%) skulls did not show any metopic suture in any form. 46 (36.5\%) skulls had either complete or incomplete metopic suture. 
Complete metopic suture i.e., metopism was found in $4(3.17 \%)$ skulls and incomplete metopic suture was seen in 42 (33.33\%) skulls. As for the subgroups of incomplete metopic suture, linear type was observed in 21 (16.66\%) skulls, U shape was found in 16 (12.59\%) skulls, V shape was seen in 5 (3.96\%) skulls. Unlike the previous studies, the other subgroups of incomplete metopic suture were not found in the present study.

\begin{tabular}{|c|c|c|c|c|}
\hline $\begin{array}{c}\text { No. of skulls } \\
\text { without metopic } \\
\text { suture }\end{array}$ & $\begin{array}{c}\text { No. of skulls } \\
\text { with metopism }\end{array}$ & $\begin{array}{c}\text { No. of skulls with } \\
\text { incomplete } \\
\text { metopic suture }\end{array}$ & $\begin{array}{c}\text { Total skulls with } \\
\text { metopic suture }\end{array}$ & $\begin{array}{c}\text { Skulls included } \\
\text { in the study }\end{array}$ \\
\hline $80(63.49 \%)$ & $4(3.17 \%)$ & $42(33.33 \%)$ & $46(36.5 \%)$ & 126 \\
\hline \multicolumn{2}{r}{ Table 1: Showing the incidence of metopic suture } \\
\hline
\end{tabular}

DISCUSSION: The findings of the present study are compared with the findings of other research workers.

\begin{tabular}{|c|c|c|c|}
\hline Research worker & Year of study & Race & $\begin{array}{c}\text { Percentage of } \\
\text { metopism }\end{array}$ \\
\hline \multirow{5}{*}{ Bryce. et al(5) } & \multirow{5}{*}{1915} & European & $8.70 \%$ \\
\hline & & Scottish & $9.50 \%$ \\
\hline & & Mongolian & $5.10 \%$ \\
\hline & & Australian & $1 \%$ \\
\hline & & Negro & $1.20 \%$ \\
\hline Keith. et al (1) & 1948 & Subject to race & $3.80 \%$ \\
\hline Inderjit and Shah(6) & 1948 & Indian(Punjabis) & $5 \%$ \\
\hline \multirow{2}{*}{ Woo. et al (7) } & \multirow{2}{*}{1949} & Mongoloids & $10 \%$ \\
\hline & & Negroids & $2 \%$ \\
\hline \multirow{3}{*}{ Breathnach. et al (8) } & \multirow{3}{*}{1958} & European & 7 to $10 \%$ \\
\hline & & Yellow races & 4 to $5 \%$ \\
\hline & & Africans & $1 \%$ \\
\hline Romanes. et al(2) & 1972 & Europeans & $8 \%$ \\
\hline Das. et al(9) & 1973 & Indian (U.P) & $3.31 \%$ \\
\hline Berry. et al(10) & 1975 & Various ethnic groups & $7.4 \%$ \\
\hline Agarwal. et al(11) & 1979 & Indian (Kanpur) & $2.66 \%$ \\
\hline Ajmani. et al(12) & 1989 & Nigerians & $3.4 \%$ \\
\hline Bilodi. et al(13) & 2003 & Nepalese & $3.92 \%$ \\
\hline Castilho. et al(14) & 2006 & Brazilian & $7.04 \%$ \\
\hline Murlimanju. et al(15) & 2010 & Indian & $1.2 \%$ \\
\hline Hussain sahib S. et al(16) & 2010 & South Indian & $3.2 \%$ \\
\hline S. Chandrasekaran et al(17) & 2011 & South Indian & $5 \%$ \\
\hline Gupta R. et al(18) & 2012 & Indian ( U.P) & $5 \%$ \\
\hline Chakravarthi. K. K et al(19) & 2012 & South Indian & $6.25 \%$ \\
\hline William F Masih. et al(20) & 2013 & Indian (Rajasthani) & $6.5 \%$ \\
\hline Present Study & 2014 & Indian (Assamese) & $3.17 \%$ \\
\hline
\end{tabular}


Thus it is seen that the findings of the present study correlates with the findings of Keith et al (1948), Das et al (1973), Ajmani et al (1989), Bilodi et al (2003) and Hussain sahib S et al (2010). It seems that the incidence of metopism is quite low in Australians (1\%), Negroids (2\%) and Africans (1\%) but higher in Europeans (8.7\%), Scottish (9.5\%), Mongoloids (10\%) and Brazilians (7.04\%).

\begin{tabular}{|c|c|c|c|c|c|c|c|}
\hline \multirow{2}{*}{$\begin{array}{l}\text { Workers with } \\
\text { year of study }\end{array}$} & \multicolumn{6}{|c|}{ Subgroups of incomplete metopic suture (in \%) } & \multirow{2}{*}{$\begin{array}{c}\text { Total no. of } \\
\text { incomplete } \\
\text { metopic } \\
\text { suture } \\
\text { (in \%) }\end{array}$} \\
\hline & Linear & $\begin{array}{c}\text { U } \\
\text { shaped }\end{array}$ & $\begin{array}{c}\text { V } \\
\text { shaped }\end{array}$ & $\begin{array}{l}\text { Inverted } \\
\text { U shaped }\end{array}$ & $\begin{array}{c}\text { H } \\
\text { shaped }\end{array}$ & $\begin{array}{c}\text { Y } \\
\text { shaped }\end{array}$ & \\
\hline $\begin{array}{l}\text { Inderjit \& Shah et } \\
\mathrm{al}^{(6)},(1948)\end{array}$ & & & & $11.25 \%$ & $1.25 \%$ & $1.25 \%$ & \\
\hline Das et al,(9) (1973) & & & $1.01 \%$ & $1.93 \%$ & & $0.28 \%$ & $17.57 \%$ \\
\hline $\begin{array}{l}\text { Agarwal et al,(11) } \\
\text { (1979) }\end{array}$ & $23.12 \%$ & & $3.25 \%$ & $2.43 \%$ & $1.57 \%$ & $1.96 \%$ & $35.51 \%$ \\
\hline $\begin{array}{l}\text { Ajamani et al,(12) } \\
\text { (1989) }\end{array}$ & $24.27 \%$ & & $0.49 \%$ & $0.97 \%$ & $3.88 \%$ & & $31.57 \%$ \\
\hline $\begin{array}{l}\text { Shanta } \\
\text { Chandrasekaran et } \\
\mathrm{al},(17)(2010)\end{array}$ & $17 \%$ & $15 \%$ & $7.5 \%$ & & & & $40 \%$ \\
\hline $\begin{array}{l}\text { Chakravarthi K.K et } \\
\text { al,(19) (2012) }\end{array}$ & $18.75 \%$ & $10 \%$ & $10 \%$ & & & & $38.75 \%$ \\
\hline $\begin{array}{l}\text { William F Masih et } \\
\text { al,(20) (2013) }\end{array}$ & $20 \%$ & $8 \%$ & $6 \%$ & & & & $34 \%$ \\
\hline $\begin{array}{l}\text { Present Study } \\
\text { (2014) }\end{array}$ & $16.66 \%$ & $12.69 \%$ & $3.96 \%$ & & & & $33.33 \%$ \\
\hline
\end{tabular}

In the present study, the linear subgroup of incomplete metopic suture is found to be $16.66 \%$ which resembles the findings of Shanta Chandrasekaran et al (2010) and Chakravarthi K.K et al (2012).We found $12.69 \%$ of $U$ shaped incomplete metopic suture which is in between the findings of these two workers who found it to be $15 \%$ and $10 \%$ respectively .Our finding of $\mathrm{V}$ shaped incomplete metopic suture to be $3.96 \%$ is quite similar to the findings of Agarwal et al (1979) who found it to be $3.25 \%$. However in our study we did not observe any other subgroup of incomplete metopic suture as recorded by previous authors except that one skull with linear incomplete metopic suture near nasion showed interrupted metopic suture also. (Picture 4)

\begin{tabular}{|l|c|c|c|}
\hline \multicolumn{1}{|c|}{ Research workers } & Year of study & $\begin{array}{c}\text { Part of India } \\
\text { where studied }\end{array}$ & Percentage \\
\hline Inderjit \& Shah et al(6) & 1948 & Punjab & $5 \%$ \\
\hline Dixit \& Shukla(21) & 1968 & U.P & $2.53 \%$ \\
\hline Das et al(9) & 1973 & U.P & $3.31 \%$ \\
\hline
\end{tabular}


ORIGINAL ARTICLE

\begin{tabular}{|l|c|c|c|}
\hline Agarwal et al(11) & 1979 & Kanpur & $2.66 \%$ \\
\hline Herker NG et al(22) & 1981 & Maharastra & $3 \%$ \\
\hline Murlimanju BV et al ${ }^{(15)}$ & 2010 & Not spacified & $1.2 \%$ \\
\hline Hussain sahib S et al(16) & 2010 & South India & $3.2 \%$ \\
\hline Mangalgiri et al(23) & 2010 & Central India & $3.95 \%$ \\
\hline S Chandrasekaran et al(17) & 2011 & South India & $5 \%$ \\
\hline Gupta R et al(18) & 2012 & U.P & $5 \%$ \\
\hline Chakravarthi K. K et al(19) & 2012 & South India & $6.25 \%$ \\
\hline William F Masih et al ${ }^{(20)}$ & 2013 & Rajasthan & $6,5 \%$ \\
\hline Present study & 2014 & Assam & $3.17 \%$ \\
\hline \multicolumn{2}{|l|}{ Table 4: Showing the incidence of metopism in different parts of India } \\
\hline
\end{tabular}

Thus it is obvious that the incidence of metopism is gradually on rise in the South Indian states \& the state of U.P. According to Dixit \& Shukla ${ }^{(21)}$ in 1968, the incidence of metopism in U.P. was only $2.53 \%$. It is almost double now as reported by Gupta R et al (18) in 2012. The same has happened in South India. In a study carried out by Hussain Saheb S et al,(16) the metopism was found to be only $3.2 \%$ in 2010 . But it has risen to $6.25 \%$ in a short spun of just two years according to Chakravarthi KK et al.(19) Incidence of metopism in the present study is very similar to the study by Das et al,(9) Hussain Saheb S et al,(16) Herker NG et al(22) \& Mangalgiri et al.(23)

CONCLUSION: It can be concluded from this study that the presences of metopic suture vary considerably from region to region and also among different races. Incidence of metopism is much less as compared to the incidence of incomplete metopic suture. Metopic suture can be misdiagnosed as a vertical fracture of the frontal bone in patients with head injury.

\section{REFERENCES:}

1. Keith A. Human Embryology and Morphology, $6^{\text {th }}$ ed. London. 1948.

2. Romanes GJ: Cunningham's Textbook of Anatomy, 11 th ed, London, Oxford University Press, 1972; 133.

3. Warwick R \& Williams PL: Grey's Anatomy, 40th ed, London, Longmans.

4. Hamilton WJ: Textbook of human anatomy, Macmillan \& co. London, $2^{\text {nd }}$ ed, 1976, p 60.

5. Bryce TH: Osteology \& Anthrology. Quains elements of Anatomy. $11^{\text {th }}$ ed. London, Longmans Green; 1915; 177.

6. Inderjit \& Shah MA: Incidence of frontal or metopic suture amongst Punjabi adults. Indian Medical Gazatte, 1948; 83: 507.

7. Woo, Ju- Kong: Racial \& sexual differences in the frontal curvature and its relation to metopism. American Journal of Physical Anthropology. 1949; 7: 215-26.

8. Breathnach AS: Frazer's Anatomy of the human skeleton, $5^{\text {th }}$ ed. London, Churchill Livingstone.

9. Das AC,Saxena RC \& Beg MAQ: Incidence of metopic suture in U.P subjects. Journal of the Anatomical Society of India, 1973; 22: 140.

10. Berry AC: Factors affecting the incidence of nonmetrical skeletal varients. J Anat. 1975; 120: 519-535. 
11. Agarwal SK, Malhotra VK, Tiwari SP: Incidence of the metopic suture in adult Indian crania. Acta Anat (Basel), 1979; 105: 469-74.

12. Ajmani ML, Mittal RK \& Jain SP: Incidence of metopic suture in adult Nigerian skulls. J. Anat. 1983; 137(1): 177-83.

13. Bilodi AK, Agrawal BK,Mane S, Kumar A: A study of metopic sutures in human skulls. Kathmandu Univ Med J, 2003; 2: 96-99.

14. Castilho SMA, Oda YJ Santana GDM: Metopism in adult skulls from Southern Brazil, Int J Morphol, 2006; 24 (1): 61-66.

15. Murlimanju BV, Latha V Prabhu, Mangala $M$ et al: Median Frontal Sutures- Incidence, morphology \& their surgical, radiological importance. Turkish Neurosurgery, 2011; 21:4, 489493.

16. Hussain Saheb S, Mavishetter GF, Thomas ST, Prasanna LC: Incidence of metopic suture in adult South Indian skulls.2010, 2(4): 223-226.

17. Shanta Chandrasekaran, Deepti Shastri: A study on Metopic Suture. International Journal of Basic Medical Science. 2011; 1:379.

18. Gupta R, Usman N, Zaidi SHH: A study of metopic suture in adult Indian skulls. National journal of integrated research in medicine, 2012; 3: 82.

19. Chakravarthi KK, Venumadhav N: Morphological study of metopic suture in adult South Indian skulls. Int. Journal of Medical \& Health sciences, 2012, 1(2): 23-28.

20. William F Masih, S Gupta, Saraswat PK, Aggarwal SK: Autopsy study of metopic suture incidence in human skulls in Western Rajasthan. National Journal of Medical Research, 2013, vol3, issue 1, 63-65.

21. Dixit CS \& Shukla PL: Metopic suture in human crania. J Anat. Soc. India, 1968.

22. Herker NG,Jahagirdhar PL \& bhode DD: The study of metopism in Maharastrian. J Anat soc. Of India.1981; 29-31.

23. Mangalgiri AS, Satpathi DK, Razvi R, Naik DC: Study of metopism in skulls of central India. Indian Journal of Forensic Medicine Toxicology, 2010, 4(1): 74-77.

\section{AUTHORS:}

1. Rubi Saikia

\section{PARTICULARS OF CONTRIBUTORS:}

1. Associate Professor, Department of Anatomy, Assam medical college, Dibrugarh, Assam.

\section{NAME ADDRESS EMAIL ID OF THE CORRESPONDING AUTHOR: \\ Dr. Rubi Saikia, \\ Associate professor, \\ Department of Anatomy, \\ Assam medical college, \\ Dibrugarh-786002. \\ Email:drrubisaikia@gmail.com}

Date of Submission: 02/09/2014.

Date of Peer Review: 03/09/2014.

Date of Acceptance: 09/09/2014.

Date of Publishing: 15/09/2014. 